University of Louisville

ThinkIR: The University of Louisville's Institutional Repository

Electronic Theses and Dissertations

1943

\title{
The potentiometric determination of zinc in Dowmetal alloys.
}

James S. Goodman

University of Louisville

Follow this and additional works at: https://ir.library.louisville.edu/etd

Part of the Inorganic Chemistry Commons

\section{Recommended Citation}

Goodman, James S., "The potentiometric determination of zinc in Dowmetal alloys." (1943). Electronic Theses and Dissertations. Paper 2039.

https://doi.org/10.18297/etd/2039

This Master's Thesis is brought to you for free and open access by ThinkIR: The University of Louisville's Institutional Repository. It has been accepted for inclusion in Electronic Theses and Dissertations by an authorized administrator of ThinkIR: The University of Louisville's Institutional Repository. This title appears here courtesy of the author, who has retained all other copyrights. For more information, please contact thinkir@louisville.edu. 
DUTVERTIY OF LOUISVIITE

THF POTEWTIOMETRIC DETERUTNATION OP 2 THO IN DOWUETAL ALLOXs

A DTSSERTATION

SUBMIIIED TO WHE FACUTTX

OP THE GRADUATE SCHOOL OP THE UNIVIASITY OP IOUISVILIE

IN PARTIAL FULFTLLMBIT OF THE

REQUIRMMENTS FOR THE DEORES

OF UASTER OP SCIMUCE

DEPARTUEMT OF CFENISTRY

BI

JAITS $S$. OOODMAX

IEAR

1943 


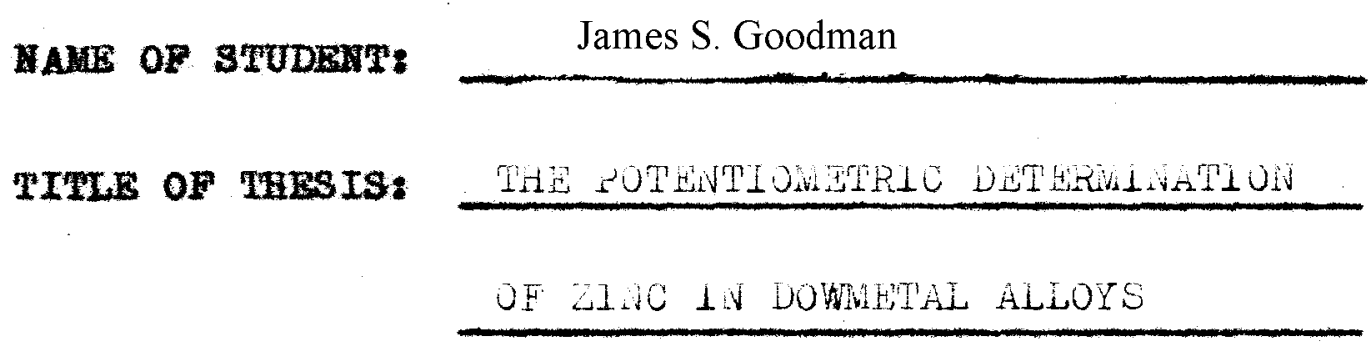

APPROVED BY READINO COMMTTEEE COMPOSED OF THE POLIOWINO YRUBERS:

C.C. Vernon

G. L. Corley

NAME OF DIRECTOR:

G. L. Corley

DATB: $5 / 19 / 43$ 
TABLE OF CONTEHTS

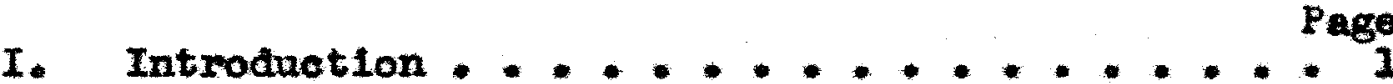

II. Bquipmont .................... 3

III. Theory. ...................... 8

IV. Experimental $\ldots \ldots \ldots+\ldots, \ldots \ldots$

a. Bxperiment Ho, $1 \ldots \ldots \ldots \ldots$

b. Experiment Ho. 2............... 15

o. Experiment Ho, $3 \ldots \ldots \ldots$

a. Bxperiment Ho. $4 \ldots \ldots \ldots \ldots$

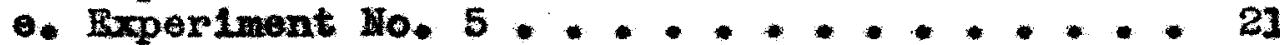

f. Experiment No. $6 \ldots \ldots \ldots \ldots$

g. Experiment ho. $7 \ldots \ldots \ldots$

h. Experiment Ho, $8 \ldots \ldots \ldots$

1. Bxperiment Ho, $9 \ldots \ldots$

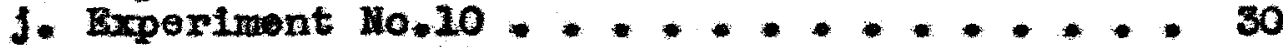

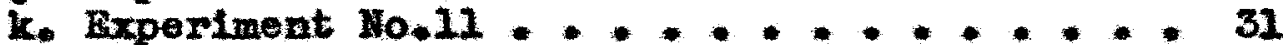

1. Experiment Ho.12 $\ldots \ldots \ldots \ldots \ldots$

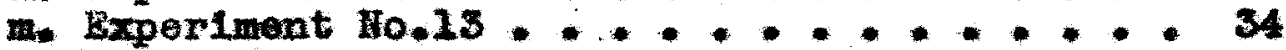

V., Surmary .................... 36

VI. Blbllography. $\ldots \ldots \ldots \ldots$

vII. Acknowledgment. ................ 39 


\section{IATRODUCTION}

This research was begun because of a desire to find a quicker, easier, and more accurate means of routinely determining zine in certain of the Dowmetal magnesium alloys.

The analytical procedure recommended by the Dow Chemical Company for the determination of zinc in their alloys is a volumetrie method involving the titration of the zinc solution with potassium ferrocyanide using diphenylbenzidine as an internal indicator. (2) This method has been found to be very slow, and the exact end point of the analysis is not sufficlently sharp to pernit good check analysis to bo rum on the same sample.

A few months previousiy I worked out a rapid potentiometric method fur the analysis of Aluminum in Dowmetal alloys. In this research a Flsher Electrometric iltrimeter was employed which is a very compact vacuum tube voltmeter--potentiometer instrument using an electron ray tube to Indicate the end point of the titration instead of the usual galvonometer. 
The speed and accuracy of this method led to a bellef that a potentlometric method might be worked out for the analysis of zino in Dowmetal alloys using the samo Fisher apparatus.

with this in mind the literature was searched to see just what had been done by others in applying a potentiometric method to the determination of zinc. Kol thoff and Furman (7) have discussed the direct titration of zinc with potassium ferrocyanlde using a potentiometric system. Kolthoff found however that many factors entered into the accuracy of his method (time, temperature, addition of certain salts, ect.). and he leaves us with no positive conclusions drawn as to any certain method.

Sturges (13) has gone much further in solving the problem of time for equilibrium to be reached between the zine and the ferrocyanide by adding an excess of ferrocyanide to the zine samples and back titrating the excess with ceric sulfate using a Titrimeter and a platinum-tungsten electrode. But here again the inveatigation seemed to be of preIIminary nature, and furthermore was done on pure zinc samples rather than on alloys. 


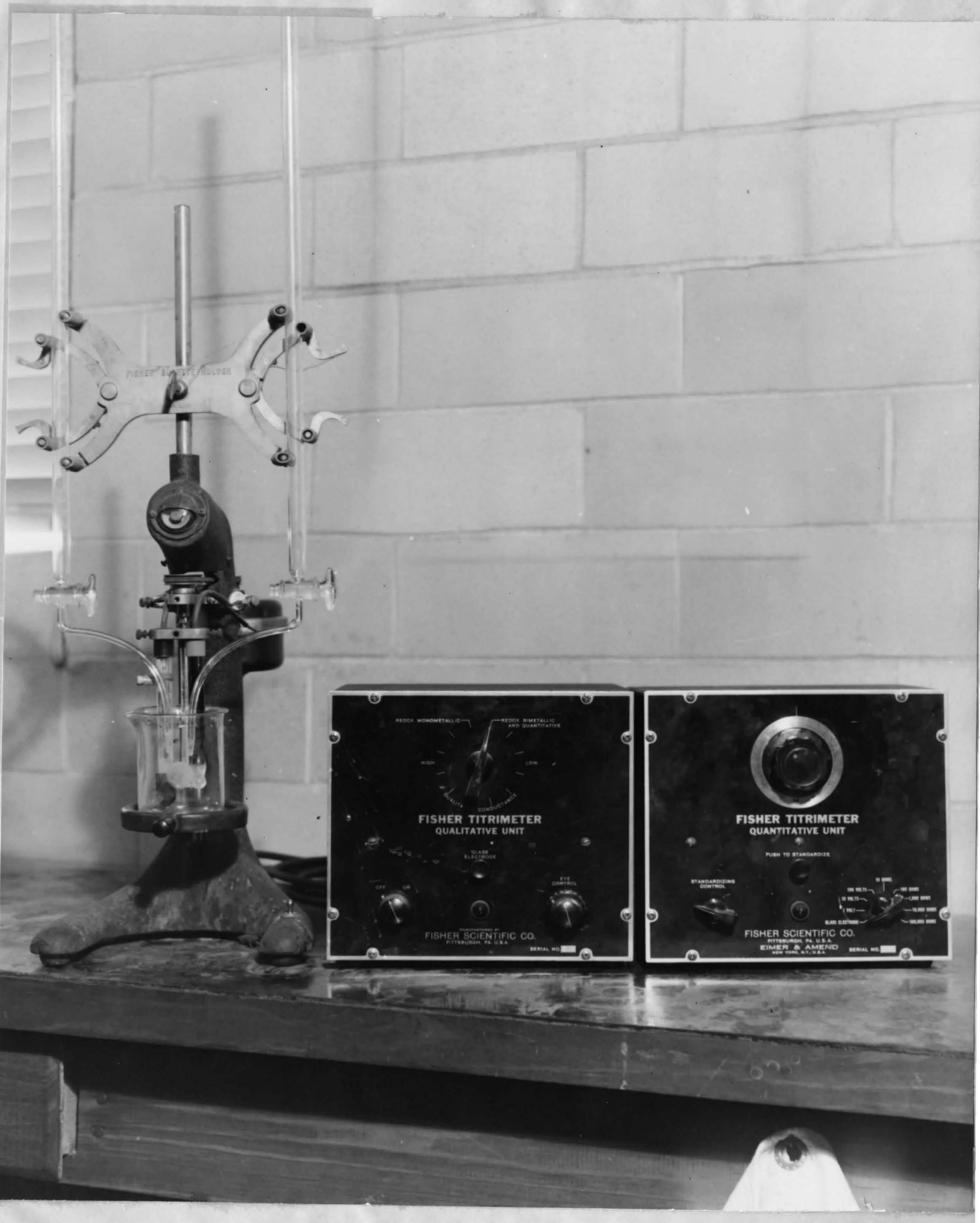




\section{EQUTPMETT}

The apparatus essential to the sucoess of this researoh consisted of an Alnsworth Chainomatio Analytical Balance, a set of analytical weights, class S, chronium plated, and a Fisher Electrometric Titrimeter, Senior Model, with glass, calomel, platinumplatinum, and platinum-tungsten electrodes.

The acouracy of the anslytical welghts and the special burettes supplied with the Iitrimeter had been found in previous work to be of a very high degree, and it was not deemed necessary to take time from the problem by repeating the usual callbration work.

The Fisher Titrimeter, as shown in the photograph on the opposite page, consists of a stand housing the electron ray tube or "Flectric Eye" which acts as a galvonometer in indicating the end point of a titration, the stirring motor, a burette clamp, and a support for the boaker during the titration. It further consists of a "qualitative Unit" which is essentially a vacuum tube voltmeter amplifier, and a "Qualitative Unit" which Introduces a wheatstone-Briage circult for use in pH determinations with the glasscalomel electrode system. The electrode holders are 
so designed as to make the interchange of the electrodes and electrode-stirrers a quick and easy matter. The stirring motor is connected with the stirrer by means of a spring belt.

The reagents used were of C.P. quality and were obtalned from reputable manufacturers. They consisted of potassium ferrocyanide, ceric sulfate, o-phenanthroline ferrous complex indicator, ammonium sulfate, ammonium chloride, amonium persulfate, sodium oxalate, pure zine metal, potassium permangenate, hydrogen sulfide, diphenylbenzidine indicator, tartaric acld, hydrochloric acla, sulfuric acld, formic acld, and amonium hydroxide.

The potassium ferrocyanide solution was made up by dissolving $18 \mathrm{~g}$, of $\mathrm{K}_{4} \mathrm{Pe}(\mathrm{CN})_{6}$ in liter of distilled water and allowing the solution to stand for three weoks in order for complete equilibrium to be reached. It was standardized ageinst standard zine solution immediately before use each time, the mothod depending upon the zinc method used as this was consldered to give the utmost in accuracy. Cerlc sulfate was a rolatively now reagent, and considerable time was spent in investigating its 
propertles. It forms two compounds, cerous in whlch it has valence of 3 and is colorless, and ceric in which it has valence of four and has an orange color. As compared with potassium permanganate it is fully as strong as an oxidizing agent, is very stable, can be used in the presence of hydrochloric acid, and has only one possible valence change. It was made up by dissolving $33.25 \mathrm{~g}$. of anhydrous $\mathrm{Ce}\left(\mathrm{SO}_{4}\right)_{2}$ in $1 \mathrm{H}$. sulfuric acid and making the total volume to 1 Iiter with the same $1 \mathrm{~N}$. sulfuric acid solution, 1to own color belng used as an indleator. Three runs were as follows--

1. Wt. $\mathrm{Na}_{2} \mathrm{C}_{2} \mathrm{O}_{4}--0.1866 \mathrm{~g}$. 2. wt. $\mathrm{Na}_{2} \mathrm{C}_{2} \mathrm{O}_{4}--0.1260 \mathrm{~g}$.

$$
\begin{aligned}
& \text { 11. } \mathrm{Ce}\left(\mathrm{SO}_{4}\right) \mathrm{2}^{--24.95} \\
& \text { 112. } \mathrm{Ce}\left(\mathrm{SO}_{4}\right) 2-16.84 \\
& N=\frac{0.1866}{24.95 \times 0.067} \\
& N=\frac{0.1260}{16.84 \times 0.067} \\
& \mathrm{~N}=0.1116 \\
& N=0.1117 \\
& \text { 3. Wt. } \mathrm{Na}_{2} \mathrm{C}_{2} \mathrm{O}_{4}-0.1230 \mathrm{~g} \text {. } \\
& \text { m. } \mathrm{Ce}\left(\mathrm{SO}_{4}\right)^{2-16.45} \\
& =\frac{0.1250}{16.45 \times 0.067} \\
& N=1.1116
\end{aligned}
$$

The agreement obtained on the three muns was considered 
to be very good; in no case was there any doubt as to the end point of the titration. The temperature was kept just below the bolling point.

The o-phenanthroline ferrous complex ind1cator was obtained in the prepared form. It sometimes bears the trade name "Feroin".

The amonium sulfate and ammonium chloride were used in crystaline form, simply being added to the solutions for certain purposes. These will be discussed under the experiments in which they were used.

The tartaric acid solution was made up by dissolving $25 \mathrm{~g}$. of tartaric acld in distilled water and making up to $500 \mathrm{ml}$.

The diphenylbenzidine indicator solution was made up by dissolving $0.5 \mathrm{~g}$. of diphenylbenzidine in $50 \mathrm{ml}$. of sulfuric acld (sp. gr. 1.84).

The standard zino solution was made up by welghing out very accurately $4 \mathrm{~g}$. of pure zinc metal and dissolving in hydrochloric acld $(124)$. Inis was then diluted to one liter with distilled water. The zinc content of this solution was $0.004 \mathrm{~g}$. per ml.

A formate buffer solution was prepared by diluting $200 \mathrm{ml}$. of formic acld ( $\mathrm{sp} . \mathrm{gr} .1 .20$ ) to $970 \mathrm{ml}$. 
with distilled water and adding $30 \mathrm{ml}$. of ammonium hydroxide (sp. gr. 0.90$)$.

The hydrogen sulfide used was obtained in small cylinders from the Flsher Scientific Co., and was of C.P. analytical quality.

The other reagents not mentioned specifically here will be discussed where ised. 


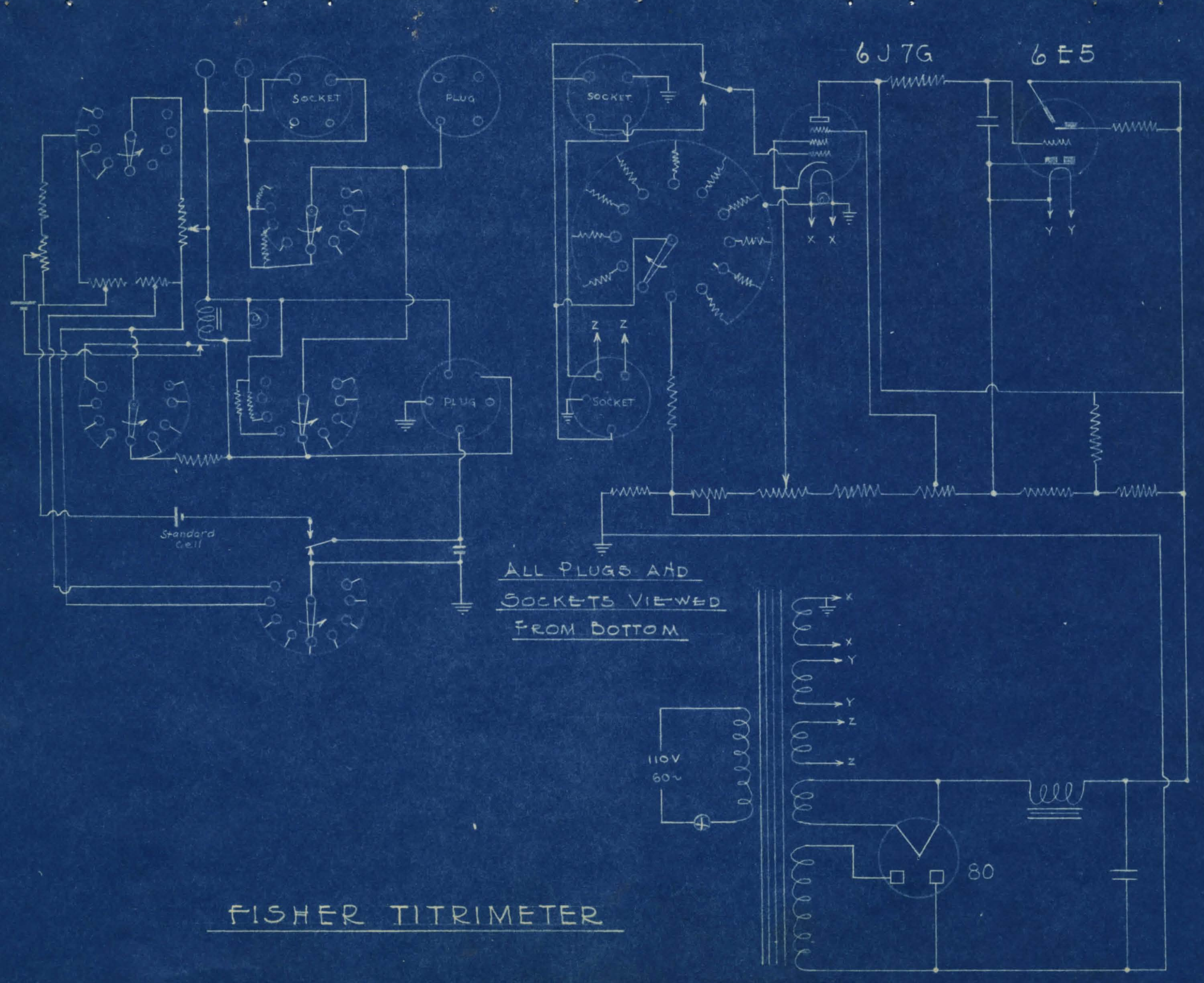


THEORY

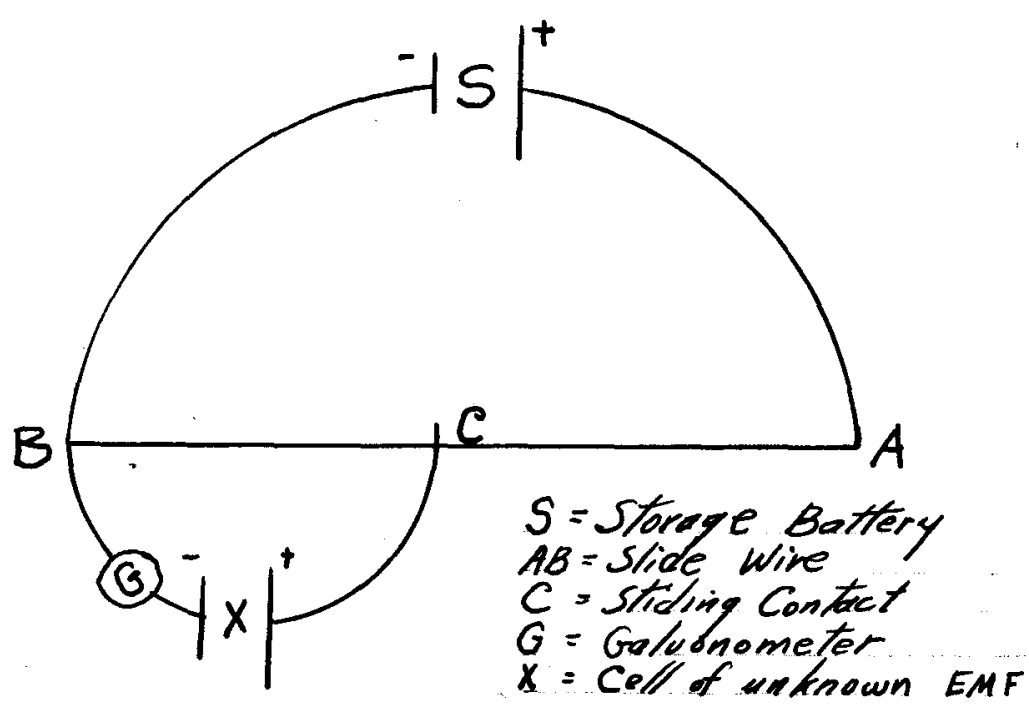

A detalied description of the wiring diagram of the Flsher Electrometric Titrimeter is beyond the scope of this investigation, although the alagram is shown on the opposite page. The principle involved Is that of the classical potentlometric method. $(5,8)$ While there is no known method which is roasonably reliable for measuring a single potential difference, it is possible to measure the potential of any given electrode by means of another electrode whlch has a constant potential. Such an electrode is known as a standard half-0e11. In the following work the olectrode having the constant known potential w111 be referred to as the reference electrode, and the electrode whose potential changes during the course of a titration as an indicator electrode. 
The principle of the potentlometer method consists in balancing the potential difference that Is to be measured against a known opposed potential difference. When such balance is reached it is Indicated by a null point on the galvonometer or by a steady slit in the electron ray tube of the Fisher Instrument.

This principle is 11lustrated by the simple diagram at the top of the precoeding page. Let $s$ be a battery having an E. $h_{0} F$. greater than that of the uniknown cell $\mathrm{X}$, the $\mathrm{E}_{*} \mathrm{H}_{*} \mathrm{~F}$. of which we want to determine. SA and SB are of heavy copper so as to have a very small resistance. $A B$ is a slide wire of unterm diameter throughout its entire length so as to have a uniform fall of potential from $A$ to $B$. $C$ is a contact sliding along the wre $A B$, and is so connected to the unknown $X$ that the positive pole of $X$ corresponds to the positive pole of the battery and that the negative pole of $X$ is connected to the negative pole of the battery. Thus in the circuit CXCB there are two different electromotive forces, Eeb between $C$ and $B$ and that of $X$ wich is furnishing current in the opposite direction. $C$ ls now moved along $A B$ until $a$ 
Indicates that current is no longer flowing through CXBQ. Since $A B$ is of unfform cross section, the difference in potential between $A$ and $B$ is equal to $\frac{B C}{A B} E$, where $B$ is the electromotive force of the battery. $\frac{B C}{A B}$ is the ratlo between the resistances of $B C$ and $A B$. In this case this ratio is equal to that of the lengths of $A B$ and $B C$. If the total length of $A B$ is $1000 \mathrm{~mm}$, then the relation for $\theta$, the unknown E.M.F. of $X$ we have

$$
=\frac{B C}{1000} E=\frac{a}{1000} E
$$

where $a$ is the value road on the slide wire. $\bar{E}$ in this case is unknown, but may be easily determined by swltching $X$ out of the clrcult and throwing in its place a standard cell of known $B_{*}$ H. F. such as a weston cadnium cell.

With this elementary discussion of the potentiometer, a study of electrometric titrations may now be discussed. Such a titration may be defined as a titration in which the end point of the reaction is detected by measuring the change in potential of a suitable electrode during the titration as rererred to a standard reference electrode. In the course of this research a reversible electrode mist of necessity be dealt with, and therefore the potential can be expressed 
by the thermodyname equation

$$
E=E^{0}+\frac{R P}{P} \ln \left(a_{1}\right) 2 / n
$$

where a is the activity of the lon in question and $n$ is its velence. Furtherwore an oxidation-reduction system is used in this invest1getion, and therefore the determining factor in the potential of the indicator electrode is the ratio of the activities or concentrations of the oxidized and reduced forme and the above equation becomes

$$
B=B^{\circ}+\frac{R T}{n F} \ln \frac{a(\text { oun })}{a(10)}
$$

This equation deteraines the shape of the titration curve and the value of $5^{\circ}$ obtelned from the equilibrium constant w111 determine its position. In ordinary potentiometrie titrations. such as would be mu in routine work, it is only necessary to find the end polnt of the reaction, and the activities of the lons are not concemed. As the titration progressea the reagent is addod gradualiy until the voltage changea raplaly with the addition of fractional parts of a miliziter of the reagent. At the end point the rate of change of this potential with a small change in concentration reaches a maximum value. 
EXPERTMEHT AL

This resoarch is to find out if gine can be titrated with reasonable ease, speod, and aceuracy using a Fisher Eleotrometrio Titrimeter.

A study of both the platinum-platimum and platimum-tangaten eleotrodes to determine whlch is best sulted to the titration, w1Il be made. On the basis of the work of other investigators $(7,13)$ it 1s belleved that an indirect titration using an excess of forrooyanide and back titrating with oxidizing agent is to be preferred ovor a direct titration with the ferrocjanide.

An investigation of the effect of time of titration, texperature, aclatty, and the adition of certaln salts will also be conducted.

The success of fallure of the wethod will be measured by comparing the results obtained with several Downetal alloy standards furnished by the Dow Chemlcal Company. The sme samples will be analyod using the old volumetric procedure, and will also mun the same samples spectrographically. It wos furthermore to be determined if the sulfide separation of the Impurity elements by suitable treatment of the samplo, coula be aro ided. 


\section{BXPERIMENT No,1}

The sample used in this, as well as in the following experiments, was prepared by cesting the alloy in holf-inoh gquare bars using iron molda. It has been determined that this procedure provides fast chilling of the wetal with resulting fine grain struoture and uniformity of composition. These bara are out into thin slloes using a power samplo saw, and these sllces are taken for analjals.

In this first experiment the only intereat was In testing the instmument to seo if suitable inflection points oould be noted with the "elootric eye" of the instrument. A sample was selected at random from the regular wan of anples. A weight enlowlated to contaln 0.05 to $0.1 \mathrm{~g}$. of gine was welghed out, alssolved in hydrochloric acid, the zino separa-. tod as the surflde, and the solution placed in the titration assembly using the platinum-tungsten olectrodes. Itrating first with ferrocyanide solution a very sharp break took place after the addition of about $15 \mathrm{ml}$. This break was not permenent however, so another 10m. of ferrocyanide was edded and the volution back titrated with ceric anfate solutlon. The and point of this beak titration was quite sharp and the -ye romalned permanently in closed position. The result of this experiment, though qualltative, served 
to show that the instrument would indicate end points and that the research could be continued in a careful quantitative maner. 


\section{EXPEATHETT: 10,2}

In this experiment duplleate samples were propared from Downetal stendard Bo. H* This samplo contained

$$
\begin{aligned}
& A 1-10.17 \% \\
& m=0.28 \% \\
& 2 n-2.06 \%
\end{aligned}
$$

The treatment of the sample was as follows: The wolght of sample was oalculated to contain 0.05 to 0.1 8. of zinc. The samples wore dissolved in hydrochloric ac1d uaing $7.5 \mathrm{mt}$. per grax of sample and an exeess of 10mi. When solution was complete they were alluted to $200 \mathrm{ml}$. and culfided for $3 \mathrm{mlnutes}$ and filtered. The filtrate was bolled to expel the $\mathrm{H}_{2} \mathrm{~s}, 50 \mathrm{ml}$. of tartaric aold solution was added (to prevent the formation of aluminum hydroxtde) and the sample noutralled to mothyl red with amonive hydroxide (1:1). $25 \mathrm{ml}$. of formate burfer wore added, the solutions hoated to bolling and sulfided for 15 mimutes with a rapld stream of Hzs. The sine sulfide was dissolved from the fllter paper with hot HCI $(1: 4)$, bolled to expel H $\mathrm{H}_{\mathrm{S}}$, and mado neutral to 1 thme with amonium hydroxide. $20 \mathrm{~g}$. of amonium chloride and $15 \mathrm{mlt}$. auffuric aold (2:4) were added, and the samples vere ready to titrate. 
The above procedure for the treatment of the aemplo is the ame as that used for the volumetrie titration as recommended by the Dow Chomicel Company (2). It was thought that until the findings showed differentiy anch a proesdure wight well be used for, if such troatment prior to titration is sultablo for alreot volumetrie titration. It shovid also bo altable for a potentiometrie titration. The data and results are as follows-

Semple Ho. I

wt. sample $-2.6423 \mathrm{~g}$.

w. $\mathrm{K}_{4} \mathrm{Pe}(\mathrm{ON})_{6}-30.00$

w. $\mathrm{Ce}\left(\mathrm{SO}_{4}\right)_{2}-\quad 7.59$

\& in -2.07
Samplo Ho. II

wt. amplo - $2,8010 \mathrm{~g}$.

m. $\mathrm{K}_{4} \mathrm{Fe}(\mathrm{CH})_{6}-30,00$

w. $\mathrm{Co}\left(\mathrm{SO}_{4}\right)_{2}-6.64$

\%n -2.08

The platinum-tungaten eleotrode syatem was used in both titrations and time allowed between the addition of the ferrocyanide and the back titration with corle mifate was 20 minutes. This walt was allowed to be sure thatequilibrius was establiahed in the sine ferrocyenide precipitation.

A aemple of standard zino solution was run at the same times as the unknown to standardiso the ferrocyanide. 
A falmy good deflection of the eloctric eye was noted as the forrocyantde was being added, and upon back titration with the cerle alfate very pronounoed effect was noted, the change at the end polnt being from completely open to completely closed. The results are also in rery close agreement w the theoretical value of $2.06 \%$

The result obtalnod in this first oxperiment were wach better than one would normaliy expect in the first quantitative run of a research determination, in fact, they would justify a claim for succesa if they coula be proven to hold in all cases. However, this was not know, and many factor could possibly enter h 


\section{Expardourat Ho,s}

In order to determine if the same degree of acouracy alght be obtalnod on atforent semple of a alghtly alfferent alloy. two semples of Downetal standard No. II were propored in exactly the semo way as In the previous expertmont. A standara sine semple was wan at the sawe time as the unlonowa ma recelved the same treatment in ordor to atandardize the ferrom oranide. The timo botween the addition of the ferrocranide and the back titration with cerle sulf ate was again 20 mimates. Tho dita and remulta are so followe1. Wt. Bample - $-3,0070$ s. 2. Wt. Sample - 2.7003g.

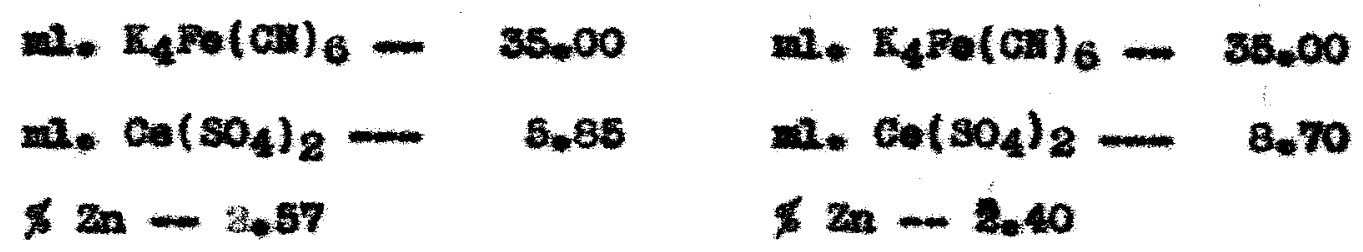
Average -2.498

The theoretical compoaltion of this anaplo was as follows-

$$
\begin{aligned}
& \text { A }- \text { - 6.30\% } \\
& \text { m }-0.36 \neq \\
& \text { 2n }-2.50 \% \\
& 81-0.28 \%
\end{aligned}
$$

In thia cave did not obtain quite as good ahocka as in the previous run, but tho acouracy it at111 consldered quite food for potentiometrie waxle 
of a routine nature. Furthermore it was as good as had boen found using the volumetric method. Agaln the -ye gave a very definite indieation of the ceric sulfate end point. 
EXPBRTMBIF Ho. 4

In this experiment auplicate samples of Dowmetal standard Ho. Here prepared. The treatment was the sawe as in the previous experimenta, but upon titration they were back titrated with 0.1 . permenganate instead of cerie surfate. The results were disappointing. Instead of the quick definite closing of the eleatrio oye at the end point of the titration as in the case of cerle sulfate, a gradual change took place which was diffleult to 800. The data and results are as follows-

Samplo 10. 1

Ht. Semple $-2.7670 \mathrm{~g}$.

m. $\mathrm{x}_{4} \mathrm{Fo}(\mathrm{CX})_{6}-30.00$

m. $\mathrm{KnmO}_{4}-6.75$

\% $\mathrm{m}-2.18$ (Theoretical $-2.50 \%$ ) $\% \mathrm{zn}-2.86$
Samplo No. 2 Wt. Sample -- 2.3454 B. m. $\mathrm{K}_{4} \mathrm{Fe}(\mathrm{CN})_{6}-30.00$ m. $\mathrm{KnO}_{4} \rightarrow \quad 5.60$

This loads to the conolusion that potassium permenganate is not as wutable for the back titration of excess ferrocyanice as the certo sulfate. 


\section{EXPERIMEXT No. 5}

The previous experiments had all employed the platinum-tungstan electrode system. This exper1ment wa made to determine the comperative sensitivity and aceuracy of the platinum-platinum electrode syotem.

In order to have a basla of comparison, a fourth sample of the seme Dormetal standard II was propared in the same rey as previeus samples. The on ahange was in the electrode syatem, cerle oulfate again being used for the back titration.

The results of this titration were uncertain. The electric eye would flutter at the addition or each inerement of reagent, and no definite end point was over reachod. It must be conoluded therefore that the platinum-platimum eleotrode syatem is totaly unauted to the potentiometrie determination of ainc. The data, though weaningless, is glven below-

$$
\begin{aligned}
& \text { Wt. Sample - } 3.5095 \mathrm{~g} \text {. } \\
& \text { m. } \mathrm{x}_{4} \mathrm{Fo}(\mathrm{cm})_{6}-30.00 \\
& \text { n. } \mathrm{Ce}\left(\mathrm{SO}_{4}\right)_{2}-50.00 \text { (Find point not reached) } \\
& \text { \& } 2 n-1
\end{aligned}
$$




\section{EXPERIMENT No. 6}

This experiment is to determine the effect of varying the acidity of the solution being titrated. S1x samples of the Downetal Standard H were welghed out and prepared ldenticalis down to the adattion of the 1:4 antririo aetd. To aamples Nos, 1 and 2 were added $10 \mathrm{ml}$. of acid; to samples Hoa. 3 and 4 wore added $20 \mathrm{ma}$. of acldy and to samplo 10.5 and 6 were added $30 \mathrm{ml}$ * of acld. They were then titrated in the same way using the platinum-tungsten electrode and ceric sulfate as the back t1trant. The data and results are given below-

Wt. sample

m. $\mathrm{K}_{4} \mathrm{Fe}(\mathrm{CH})_{6}$

mil. $\mathrm{Co}\left(\mathrm{SO}_{4}\right)_{2}$

zine

wt. semple

m. $\mathrm{x}_{4} \mathrm{~F} \in(\mathrm{CII})_{6}$

m. $\mathrm{Ce}\left(\mathrm{sO}_{4}\right)_{2}$

$\% 2 n$
Sanole 1 Sample $2(20 \mathrm{~m})$ Bample 3 $2,3945 \mathrm{~g}$. 2.4425 g* 2.3188 $\mathrm{g}$. $30.00 \quad 30.00 \quad 30.00$ $4.52 \quad 7.10 \quad 4.70$ $2.38 \quad 2,30$

8.42
Sample $4(20 \mathrm{ml})$ Sample o Sample 6(30mi) $2.5276 \mathrm{~g}$.

30.00

4.91

2.53
2.20288. 30.00

6.30

2.35
30.00

6.29

2.33 
The result agreeing most closely w1th the theoretical in the above seriea was obtained from sample 2 wth $20 \mathrm{~m}$. of $1: 4$ sulfuric acid added. The results from both 1 and 3 are much lower indicating that there is an optimum aclalty for this titration. Th1s would seem to bear out the Dow specification of $15 \mathrm{ml}$. falriy closely. It was also noted that the sharpest end point was obtalned with the No. 2 sample, and in the Ko. 3 samplo, which was most strongly acid a tendency in the eye to flutter was noticed. 


\section{BXPERIMENT Ho. 7}

This mun was made to see if the temperature of the titration had any bearing on the results obtalned. Three temperatures were arbitrarlly chosen; room tempersture of $21^{\circ} \mathrm{C}, 50^{\circ}$, and $70^{\circ} \mathrm{C}$. The upper limit was chosen because at temperatures above this hydrocyanic acla begina to form. The Dowmetal Standard $N$ was chosen for the samples, which wore prepared as in experiment No. 2. The platinum-tungsten eleetrode system was enployed and the back titration was made with cerle sulfate. Sample Hos, $I$ and 2 were titrated at $21^{\circ}$, sample Nos, 3 and 4 were titrated at $50^{\circ}$, and sample Nos. 5 and 6 were titrated at $70^{\circ}$. The data arid results are given below.

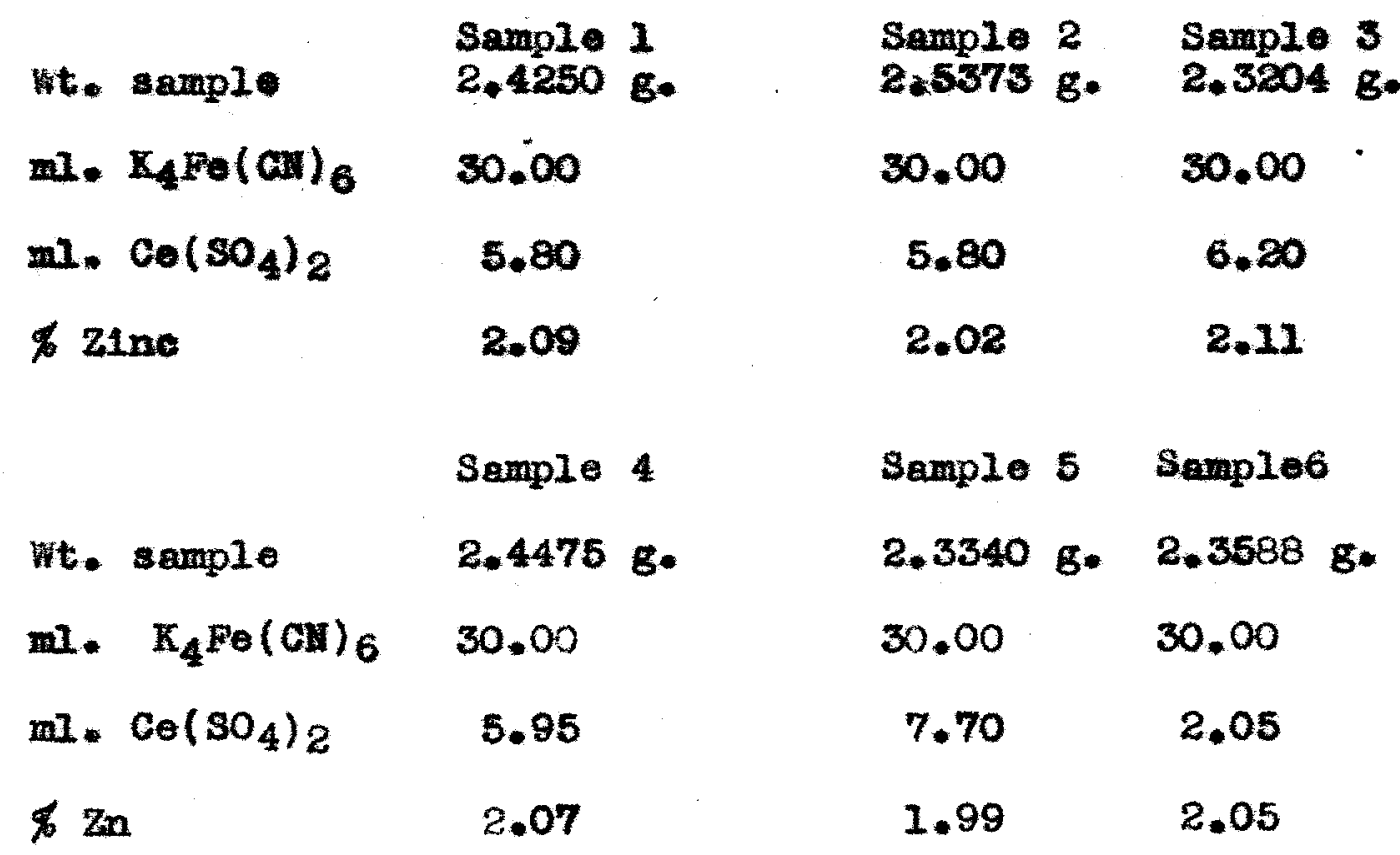


The reaults of ell six analyses show very good agrement with the theoretical value of $2.06 \%$ the conclusion belng that temperature doos not play a very Important part in the titration. However the best agreement is shown by samples 1 and 2 titrated at room temperature, and this nomal temperatare is a declded advantage where many samples have to be deterrined in routine manner. 


\section{EXPERIMENTS Ho. 8}

Several investigators havenoted that one cause of the difflculty in zinc titrations has been the slowness with which the titration mast be made in order to avold errors caused by laak of equllibrium in the zine ferrocyanide formation. (7) This diffoulty may largely overcome by adding an excess of ferrocyanide, and after a time interval back titrate the excess with an oxidizing egent. This experiment is to determine if possible the effect of different times of standing of the solutions after adding the excess of ferrocyanide but before back titrating. Elght semples of Dowmetal Standard H were prepared as In the previous experiment. Hos. 1 and 2 back titrated immediately. Nos. 3 and 4 wore allowed to stand for 10 minutes, klos. 5 and 6 for 20 minutes, and Hos. 7 and 8 for 40 mimutes. The data and results are given below.

$$
\text { Sample } 1 \text { Sample } 2 \text { Sample } 3
$$$$
\text { Wt. Sample 2.4576 g. 2.3772 g. } 2.0679 \mathrm{~g} \text {. }
$$$$
\text { m. } \mathrm{K}_{4} \mathrm{Fe}(\mathrm{CN})_{6} \quad 30.00 \quad 30.00 \quad 30.00
$$$$
\text { ml. } \mathrm{Ce}\left(\mathrm{SO}_{4}\right)_{2} \quad 4.85 \quad 5.59 \quad 6.20
$$

Zn 2.27 2.21 2.43 
Samplo 4 Samplo 5 Sample 6 Sample 7

Wt. ample 2.6438 g. $3.0534 \mathrm{~g}$. 2.7609 g* 2.6686 g*

ml. $\begin{array}{lllll}\mathrm{K}_{4} \mathrm{Pe}(\mathrm{CN})_{6} & 30.00 & 30.00 & 30.00 & 30.00\end{array}$

ml. $\mathrm{Ce}_{\left(\mathrm{SO}_{4}\right)_{2}} \quad \mathbf{4 . 3 8} \quad \mathbf{5 . 8 8} \quad \mathbf{3 . 8 6} \quad \mathbf{4 5 2}$

\% 2 n

2.53

2.53

2.48

2.46

Sample 6

$\begin{array}{ll}\text { Ht. sample } & 2.5037 \mathrm{~g} . \\ \text { mi. } \mathrm{K}_{4} \mathrm{Fe}(\mathrm{CN})_{6} & 30.00 \\ \mathrm{mi} . \mathrm{C}_{4}\left(\mathrm{SO}_{4}\right)_{2} & 5.00 \\ \mathrm{Zn} & 2.54\end{array}$

The above result soom to indicate that an Imediate back titration produces low results, but that after ten minutes 11ttle change is produced by further inereasing the time of walt. 


\section{EXPERIMHWT HO, 9}

This exporiment was designed to determino the effect of anonium ahloride upon the zinc titration. Six samples were $\operatorname{man}$ with additions of $10 \mathrm{~g} * 20 \mathrm{g*}$, and $30 \mathrm{~g}$. respectively. These analyses were made upon Dowetal Standard, and the saxples were prepared as in the preceeding experiment. Semples llos, 1 and 2 contalned $10 \mathrm{~g}$ of $\mathrm{mH}_{4} \mathrm{Gl}$, samples Hos. 3 and 4 contalned $20 \mathrm{~g}$ of $\mathrm{KH}_{\mathrm{g}} \mathrm{Cl}$, and samles Hos. 5 and 6 contalned $30 \mathrm{~g}$ of $\mathrm{MH}_{4} \mathrm{Cl}$. The data and results are given bolow.

\begin{tabular}{|c|c|c|c|c|}
\hline & Sample 1 & Sample 2 & Sample 3 & Semple 4 \\
\hline $\begin{array}{l}\text { Wt. sample } \\
\text { ml. } \mathrm{K}_{4 \mathrm{Fe}}(\mathrm{Ox})_{6}\end{array}$ & $\begin{array}{l}2.5764 \mathrm{~g} . \\
25,00\end{array}$ & $\begin{array}{l}2.4773 \mathrm{~g} \\
30.00\end{array}$ & $\begin{array}{c}2.5068 \mathrm{~g} \\
25,00\end{array}$ & $\begin{array}{c}2.5530 \mathrm{~g} \\
30.00\end{array}$ \\
\hline mil. $C o\left(8 b_{4}\right)_{2}$ & 3.85 & 5.70 & 5.20 & 5.91 \\
\hline \multirow[t]{2}{*}{$\not 2 \mathrm{zn}$} & 2.11 & 2.09 & 1.98 & 1.99 \\
\hline & Samplo 5 & & Sample 6 & \\
\hline $\begin{array}{l}\text { Wt. ample } \\
\text { mi. } \mathrm{K}_{4} \mathrm{Pe}(\mathrm{CH})_{6}\end{array}$ & $\begin{array}{l}2.5904 \mathrm{~g} \\
25.00\end{array}$ & & $\begin{array}{c}2.7212,8= \\
30.00\end{array}$ & \\
\hline m. $\mathrm{Co}\left(\mathrm{SO}_{4}\right)_{2}$ & 4.90 & & 5.44 & \\
\hline 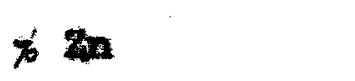 & 1.96 & & 1.94 & \\
\hline
\end{tabular}


Samples 2, 2, 3, and 4 are not so far from the theoretical value of $2.06 \%$, but nos. 5 and 6 are a littie on the low side. The tendeney seems to be for the larger amounts of $\mathrm{NH}_{4} \mathrm{Cl}$ to lower the results of the analysis. No effect could be noted in the reaction of the electrodes as measued by the activity of the electric ye at the ond point. Since the theoretical value of 2.06 lies between the revults on semples 1 and 2 , and 5 and 6 , and since $15 \mathrm{~g}$. is between the 10 and 20 used in $I$ and respectively. It seems justiflable to contimue to use the addition of $15 \mathrm{~g}$. 
RXPERIMUAY NO. 10

Th1s experiment was to determine if thexe was an appreclable atfference in the end point as shown by the eleotric eje of the Fitrimeter and that shown by an internal indicator in the solution.

For this experiment a sample was selected at random and propared in the standard way. The ferrom cjanlde was added, and after a walt of 20 ainutes 3 drops of omphenanthroline ferrous oomplex indicator was added. The titration wa's continued with the cerlo sulfate patil the elootric eyo showed an end point by a rapid closing. A further addition of two drops of the reagent produced a distinat color change in the solution from red to blue.

The above result indicated that there is a very close agreement between the electrometric end polnt and the indieator end point when the solution is titrated as above. 


\section{EXPTRTMEHT No. 11}

This experiment was mun to get a comparison botween an analysis of the alloy for zine separated in the manner desoribed in experiment 2 , and an anelysis run without any separation whatever. Accoralngly one sample was weighod out and propared in the same way a. In previous experiments. A second sample was weighed out and troted in the ame way oxoept for the aulfide precipitations. The sulfied sample was marked Ho.1 and the sample not saparated marked lo. 2. The data and results are as follows:

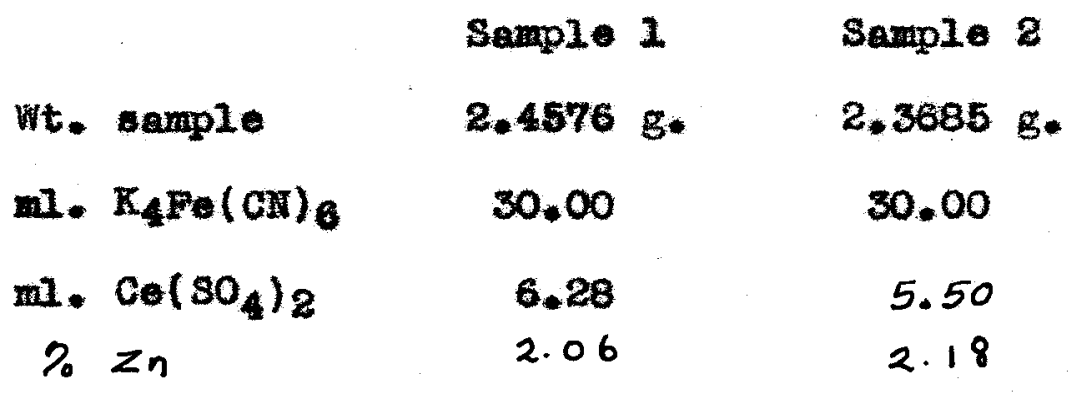

These results would seem to indicate that

the fallure to separate zine as the sulfide and redissolving causes the analysis to give reaults that are too high, al though the difference was mach less than expected. 


\section{EXPERIXENT Ho. 12}

The nesults of the provious experiment led us to wonder if possibly the presence of manganese in the solution night be causing the results to be high, bocause Kolthoff found that this element would Interfere. (7) It was declded therefore to repeat the preceeding experiment using one semplo prepared in the standard way as roference, and proparing two other samples in which we procipitated the manganese as the dioxide with amonium persulfate. Sample Ho. 1 was treated as in experiment 2; samples Nos. 2 and 3 were treated with the persulfate. The data and results are given below.

Sample 1 Sample 2 Sample. 3

wt. Semple ' 2.3389 g* 2.3728 g* 2.4206 g* ml. $\begin{array}{llll}\mathrm{K}_{4} \mathrm{P} \cdot(\mathrm{GN})_{6} \quad 30.00 \quad 30.00 \quad 30.00\end{array}$ m. $\mathrm{Ce}\left(\mathrm{SO}_{4}\right)_{2} \quad 8.58 \quad 8.60 \quad 9.50$ $\begin{array}{llll}* \text { zine } & 2.04 & 2.00 & 1.98\end{array}$

The results of these runs are in mach botter egreement with the thooretical value than the resulta in the preceeding experiment. In fact, even though 
they are still on the low side, there is good indication that by this potentlometric method the zine in magnesium alloys may be very quickly estimated in this way without any long sulfide preclpitations matever. The eye of the instrument further seomed unaffocted by the change in procedure. 


\section{EXPERIMEAT HO. 13}

In previous experiments it has been seen that the potentiometric titration of zine using an excess of potansium ferrocyantde and back titrating the excess wh cerle surfate is a usable method, and have dotermined the effect of certain factors. In this last experiment of this research our findings on six samples will be tested, running them potentiometrically, volumetrically, and spectrographically.

For the potentionetrie titrations the semples w111 be propared as in experiment ko. 2.

For the volumetric titration the samples will also be prepared as in experiment Ho, 2 , but they will be directly titrated with potasslum ferrocyanid to an end point using diphenyibenzidine as an Indiator. This is in accordence with the procedure Isted in the Dow Chemical Company Manual. (2)

For the spectrographlo deteratnation the samples were run on a Dietert grating spectrograph, using the internal standard mothod of Gerlach and Schweitzer. (4) The zine line used was 3282 A. and 
was referred to the internal standerd line of magnesium at $3074 \mathrm{~A}$.

The data and results are as follows:

Sample Ho. Potentiometric Volumetric \% the ozino

2. 59

1.98

2.16

1.92

2.77

2.17
2.53

1.80

2.13

1.86

2.73

2.11
Spectrographic Sulase

2.56

2.01

2.17

1.82

2.79

1262206

The above results soem to cloarly indleato that the potentiometric titration of zinc is a reliable method. We consider the spectrographle determination to be much more accurate and reproduceable than the volumetrie analysis, and glanee at the above table shows that the potentiometric and the spectrographle results agreo much more elosely than the volumetric. 


\section{SUUMARX}

This researoh has denonstrated that zinc oan be determined by a potentiometric titration using a Flaher Bloctrometric Titrimeter employing an electron ray tube or "electrio eye" as an indicator.

It was determined that the adaition of an excess of ferrocyanide and the aubsequent titration of the excess after equilibrium had been reached with cerle sulfate was more rellable and reproduceable than a direct titration.

Experiments showed that the use of potassium permanganate for titrating the excess of ferrocyenide was totally unsatiafactory, and that while the platinumtungsten electrode was satisfactory, the platinumplatinum eleatrode would give no results whatever.

The effect of temperature, time, aclatty, and electrolyte on the titration was studied. The temperature seemed to have little effect on the results. It was found that the solutions cowld not be immediately back titrated, but that after equiliorium had been reached time had no effect. In the case of acldity 
and electrolyte concentration in the form of $\mathrm{MH}_{4} \mathrm{Cl}$ it was found that low concentrations of both were desirable.

A coxparison of the end points shown on the same sample by the electric eyo and an internal indicator showed good agroement between the two.

Experiments run to determino the accuracy of the thod if the other constituents were not separated from the zinc were run. The first runs gave high values for alnc, but the addition of amounfum persulfate to preclpitate the manganese lessened the trouble considerably, and it is belleved that falr accuracy can be obtained.

In conclusion, it is belleved that this mothod is very desirable for the analysis of zinc in Dowmetal Magnestum Alloys. It was belleved that the aucess of this investigation was fostered by having an excellent instrument with which to work. 


\section{BIBLIOGRAPHY}

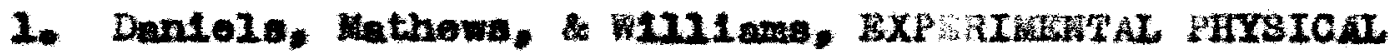

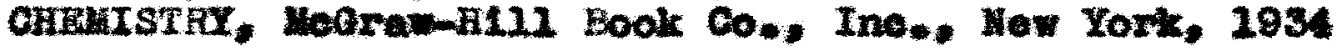

2. Dow Wenual, Dow Chemioal Company, 1941

3. Fiaher Titwimoter Hamal, Hahor solentirie co,

4. Gerlech Sahwelteer. Fotwwartons AND bitrons of

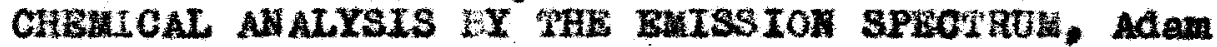
Hilger, Ltd., London, 1929

5. Getmen, P. H. Daniols P.o OUTLWE OP JFEORE

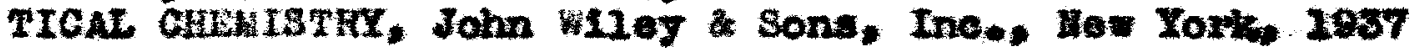

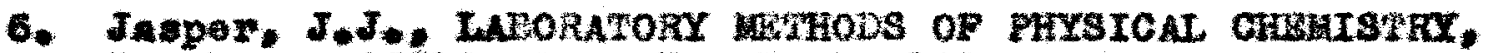
Houghton liffiln Co.. Wew York, 2938

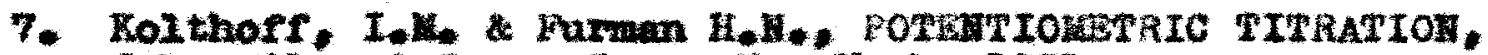
John wey sons, Inc... Wew York, 1931

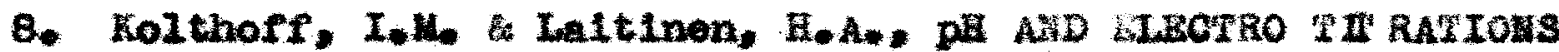
John wiley sons, Inc.., Lew York, 1941

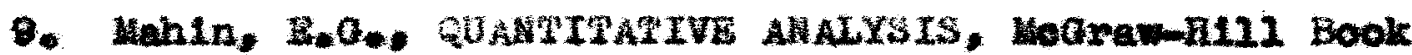
Co.: Ina.: Hew York

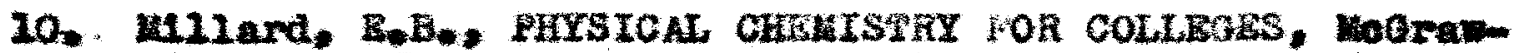
H11I Book Co,s Ince, Now York, 1036

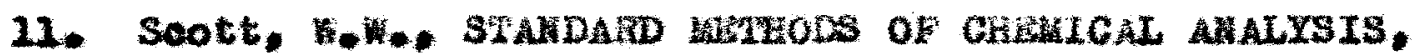
Vol. II, D. Van Hostrand Co., Ino*, Now York, 1930

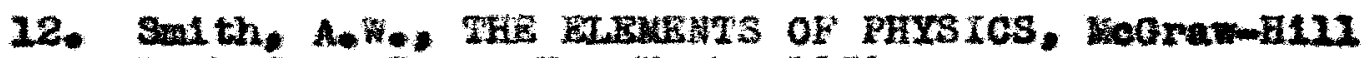
Book Co., Inc., how York, 1938

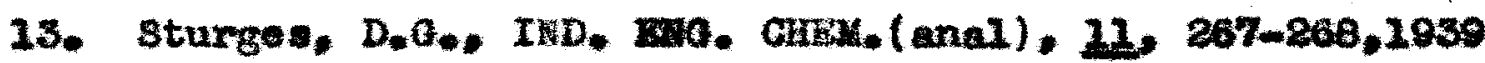

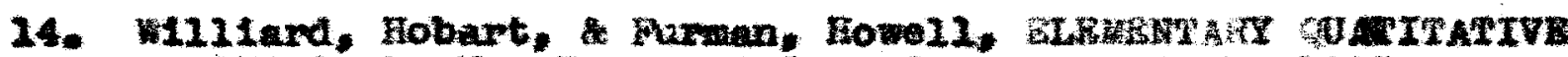
AFALXS IS, D. Van Hostrand Do., Ino., Hev York, 1933 


\section{ACKUONLEDGHEH}

I wah to express my sinoere thanks and appreclation to Dr. Orover L. Corloy for his helpful auggestions during the course of this research. I also with to express my thanles to Mr. Robert C. Boya of the Uagnosiun Control Laboratory of American Radatox and Standard Senftary Coxp. for fostering this investigation. 